\title{
An Analysis of Sangam Tamil Society's Ethical Framework as Instructed in Puranān̄ūru
}

\section{Manjula $\mathbf{M}^{1}$, Dr.B. Jai Ganesh ${ }^{2}$}

${ }^{1}$ Part Time PhD scholar, Department of Tamil, College of Science and Humanities, SRM Institute of Science and Technology, Kattankulathur, Chengalpattu District, Tamil Nadu - 603203 manjulam750005@gmail.com \&Assistant Professor, Department of Tamil, SRM Arts and Science College, Kattankulathur, Chengalpattu District, Tamil Nadu - 603203

${ }^{2}$ Head of the Department \&Research Supervisor, Department of Tamil, College of Science and Humanities, SRM Institute of Science and Technology, Kattankulathur, Chengalpattu District, Tamil Nadu - 603203

Article History: Received: 10 January 2021; Revised: 12 February 2021; Accepted: 27 March 2021; Published online: 10 May 2021

\begin{abstract}
:
Puranān̄ūru is a historical document that serves as a record of the rich cultural heritage of the ancient Tamil civilization. It is filled with ethical guidelines that will serve as guidelines to live by till the end of human civilization. Seventeen poems in Puranānūuru are considered a part of the Poruṇmolikkāñci section. This essay will analyse the ethical guidelines given to rulers on how to rule and to citizens on how to be good citizens.
\end{abstract}

\section{Introduction}

Puranānūru serves as a historical record of the lives of the ancient Tamils (the period which is referred to as the Sangam Age). The responsibilities of the Government, the rulers and administrators, Guidelines for taxation, behaviour of men, the concept of Good and Evil, High moral values, Justice, the value of education, the merits of charity are some of the topics which have been written about in great detail in the poem. This is written not just for the elite in the society (kings, upper class people) but also for the common people since it firmly believes in the power of education as a leveller of class distinction.

\section{Responsibilities of Government}

The king (since the Sangam Age was an age of Monarchy) should always be a responsible man. The example used in Puranānūuru is "like a mother who takes care of her children", the king should take care of all his citizens.

"Protect your country like you would guard a child" (Pur. 5)

From the above quotation from Puranānūuru, written by Nariverū'uttalaiyār, clearly shows that the view of the poet is that the government should always consider the welfare of all his citizens as his primary duty and that he should do his best to fulfill it.Citizens are not nourished by rice grains and water but by the loving kindness showed to them by their ruler. This being the case, the ruler who has absolute power over his subjects should not deviate in the slightest from the strict moral code which has been framed keeping in mind the welfare of the people.

"Rice is not life! Water is not life!

The king is life for this wide world!" (Pur. 186)

Mōcikīranār expresses his opinion that the king who is guided by scholars and wise men in his day to day affairs of governing the people will do an outstanding job of eliminating feelings of discontent within the kingdom and would ensure that the citizens are ruled according to the principles of justice, equality and equity.

Those who fail to stand by the principles of justice, 
Tontaimān il ilantiraiyan says that a ruler who fails to discharge the duties of a good ruler will be destroyed and will also result in the destruction of the whole well being of the population. The ruler is given absolute authority over the people and over the land which he governs. With this power comes the responsibility to govern over them with fairness.

"It is the responsibility of the king to ensure the well being of all his citizens which will include ensuring that famine over the country and starvation of the people are prevented. It is also the duty of the king to support the livelihood of the poor, the under privileged and artisans who live in the royal court. It is the ultimate responsibility of the king to prevent wars from taking place and if they do take place, to ensure that minimal damage is done to their country and to safeguard the people from the cruelties of war. ." Dr. Ku. Civappirakācattin's observations give a rough idea of the duties of the rulers.

\section{Guidelines for Taxation}

The king who is considered wise and noble will not tax his citizens unduly since an increase in taxes will eventually result in the suffering of all the people and then, the king himself. Cōlan Nalanikilli advises kings not to lay down laws that increase the taxation of the subjects to an extent that they struggle to pay it or which harrasses the livelihood of the common man.

"since all the elders in the family have have been taken by the god of death Kootruvan" (Pur. 75 )

From this line, it is evident that one of the primary duties of the king is to ensure that the government, that is to say, the ruler, should not lay a burden on the common man.

"Perpetual, poverty is death to wisdom of the wise;

When man forgets himself his glory dies" (Kural. 532)

The above line also expresses a similar sentiment. When Picirāntaiyār comes to know of the increases taxation of the people in the kingdom of Pāntiyan Arivuțainampi, he offers the following advice.

"If you reap rice paddy and make balls

for feeding elephants"(Pur. 184)

In this poem, it is mentioned that if rice grains are cut to feed elephants, it is possible to feed them for many days and that if the same elephants were let loose in the same rice fields where the rice grains were cut, then the elephants will destroy more rice grains than they will consume by trampling them under foot. Therefore, the king should not listen to the foolish advice offered by his foolish and bad ministers who may have a hidden agenda and should carefully deliberate on all schemes with the welfare of the people kept in mind before embarking on any projects of taxation. If the above advice is followed, then the kingdom will be prosperous and the families in the kingdom will also be prosperous.

\section{Manners of Men}

Good and Evil do not come from the land but, according to Puranānūru comes from the chaste manners of the men living in the kingdom. The virtue of men's morals and manners also result in the good name and the well being of the kingdom.

"If men who live there are good, you will be good land!" (Pur. 187)

Auvaiyār's words indicate the responsibilities of the men in the kingdom. It is evident that this section is meant not just for the rulers but also for every male subject in the kingdom. 


\section{Good and Evil}

The world is one. All the men living on this one planet are all related. Only the perpetrators are responsible for their actions, both good and bad. Life should be taken as it comes but with complete responsibility for our actions. There should be no distinction whatsoever about the upper classes and the lower classes. Everyone should follow the highest ideals of the Age and be ethically strong. Pūnikunnanāār's saying "Good and Evil do not come from others" (Pur, 192) expresses this idea of life advocated in Puranān̄ūru.

\section{Good and non-good}

There are many good qualities present in this world for human beings to do. There are many men who do not do any good thing during the whole time they lived on Earth. When a person does no good deeds during their prime and realizes the need to do good actions just before the approach of Death (Kütrruvan), all that will be left then would be regret. No good would come of that regret and repentance. It is also true that the opportunity to do good deeds do not come for everyone. So, it is perfectly fine if a person does not do any good deeds but it should be kept in mind that evil deeds should not be committed. If one restrains oneself from doing an evil act, it, in itself, becomes a good deed.

"Even if you don't do good deeds, avoid

doing bad ones!'(Pur. 195)

Nariverū'uttalaiyār talks about the importance of restraining from evil acts in this passage.

\section{High moral qualities}

Kadalul Māyntha Illam peruvaluti has compiled a list of highly commendable moral actions which yield goodness to the people doing it and to the nation of which the doers are a part of. Even if one gets magical food that will extend the life of a person, the morally fine thing to do would be to invite others to the feast and not just eat alone. The following are the morally commendable actions: not being lazy, having the proper fear and respect for the things that deserve such fear and respect, those who are not quick to anger, those who sacrifice their lives without a single thought of fame, those who refuse even the whole world as a prize for doing a morally reprehensible act, those who do not suffer or cause others to suffer, those who do not live for themselves but for others. Only the people displaying the above characteristics are needed for the welfare of the country.

This world exists because of men with fine morals(Pur. 182)

This poem explains this idea. For the welfare of society, humans should be aware of these high moral qualities and should follow it diligently. "It is evident from reading Puranāñūru that an individual who follows all the high moral qualities described above has the power to change the society and the world." ${ }^{2}$ Ku. Civappirakācattin's quote makes it clear.

\section{Awareness of Transience}

It is vital for humans to be aware of the fact that life on earth is transient. If one is aware of this, then good deeds will automatically spring up from a person and their minds would start functioning in a different (good) way. In a house, a member of the household has just died and the beating of the funeral drums are heard. In another house, the festival drums are also heard. In one house, the wife is weeping because the husband is away. Since all human experiences are different and since they are filled with a transitory quality, it is wiser to always avoid words that wound others and to select words that will cause happiness to others. This will also make society a better place.

"This world is cruel! May those who understand its nature, find bliss!" (Pur. 194) 
Pakkuṭukkai nankkaniyār's words express the message of transience.

\section{The Importance of Education}

Āriyappațai kațanta nețuñceliyan has compiled the benefits of education. According to him, even the mother would prefer the educated child over a child who is not educated, Governments also favour the services of the educated since they can be of use to them. Even though society was divided based on occupation, education is a great remover of such distinction since an education makes a person rise to the level of kings. It is a socialist tool which eradicates class and paves the way for equal opportunities for all citizens which leads to an equitable distribution of wealth. Since education offers so many benefits, people should treat their teachers, givers of wisdom and knowledge with great respect and give them gifts and should serve them as a student to study from them.

"It is good to learn from a teacher,

helping him during his troubles”(Pur. 183)

"It is better to get an education even if you have to beg for it!"”

These lines by Ativīrarāmapāṇtiyan demonstrates how important education was considered by ancient Tamils.

\section{The benefits of Charity}

Those who have an abundance of the basic necessities of life such as food, clothing and shelter have a moral duty to help those who are in need of it. This is the only true value of wealth.

"So, the purpose of wealth is charity." (Pur. 189)

Maturaik kaṇakkāyan̄ār makan̄ār nakkīran̄ār has emphasized on the value of charity and being generous. Kōpperuñcōlanin has also emphasized on the importance of being generous. Those who are very generous will be assured of a life in Heaven or even escape from the cycle of births and rebirths. A healthy body and a fame which is high because of one's charitable nature is a valuable treasure.Therefore, one should not fear but should also be very generous. (Pur. 214)

Kings and men listened to the instructions of the wise poets who gave these instructions and lived by those instructions. The life goal of the people of the Sangam Tamils was doing good deeds. Therefore Cāmi Citamparanāres's statement "Generosity, Ethics and a helpful mindset were the primary duties of ancient Tamils" is found to be accurate.

\section{Conclusion}

From the wisdom of Puranānūuru mentioned above, the following are the conclusions which are listed below

Puranānūuru mentions that the king should take care of all his citizens "like a mother who takes care of her children".

The king should be the life of the people, should stand in the ethical standards set by the wise poets, should guard the kingdom from enemy's attack and safeguard the property of all the citizens.

Even if there are no opportunities to do good deeds, it is emphasized that bad deeds should be avoided. Good and Evil do not come from other human beings but by the perpetrators of those actions. Manners of men and the high ethical standards set for their behaviour should always be followed at all times. The benefits of charity and the necessity of generosity are illustrated with examples. Not just wise poets but also kings have written poems to highlight the importance of moral principles. As long as the Earth 
sustains human beings on it, the ethical principles listed in the Puranānūru are valid and they would help them in the pursuit of a just and fair society where everyone has equal opportunities and equal access.

\section{Footnotes}

1. Dr. Ku. Civappirakācam, Puranān̄ūrril Vālviyal Vilumiyañkal., p. 56

2. Dr. Ku. Civappirakācam, Puranānuūrril Vālviyal Vilumiyañkal., p. 62

3. Ativīrarāmapāṇtịañ, Verrivērkai.,p. 35

4. Cāmi. Citamparanāā, Eț̣ut Tokaiyum Tamilar Paṇpāṭum., p.214

\section{Works referred}

1. Turaicāmippiḷ!ai. Auvai. Cu. Puranān̄ūrru Urai., Kalaka Velịīṭu, 154 TTK Road,Chennai-18. 1996.

2. Ativīrarāmapāṇțiyañ., Verri Vẹrkai., Korravai Patippakam. 2014

3. Civappirakācam. Ku. Punanān̄ūrnil Vālviyal Vilumiyañkaḷ, Tirukkunal Patippakam, Emji'ār Nakar,Chennai -78. 2007

4. Citamparanāār. Cāmi., Etṭuttokaiyum Tamilar Paṇpāțum, Annpini Patippakam, Caitāppētṭai Mērku,Chennai -15. 2010

5. Varatarācanāàr. Mu. Tirukkurạl teḷivurai. Kalaka veḷiyițu, 522, TTK Road, Chennai- 18. 2014. 